\title{
Serological diagnosis of typhoid fever by counterimmunoelectrophoresis
}

\begin{abstract}
The sensitivity and specificity of counterimmunoelectrophoresis using three antigenic preparations obtained from Salmonella typhi were compared with those of the Widal test in the serological diagnosis of typhoid fever. A veronal buffer extract yielded precipitation lines against $50(96 \%)$ out of 52 sera collected from patients with typhoid but against none out of 62 sera obtained from control subjects who did not have typhoid. Less satisfactory results were obtained by counterimmunoelectrophoresis when two other preparations, a protein extract (Barber antigen) and an ultrasonic lysate, were used as the antigens. By Widal test the rate of detection in patients' sera was $73 \%$ and the false-positive rate for control sera $16 \%$.

It is concluded that in an area where typhoid is endemic counterimmunoelectrophoresis using veronal buffer extract as the antigen is superior to the Widal test for serological diagnosis of typhoid fever. An additional advantage of counterimmunoelectrophoresis is that results may be obtained on the same day that the serum specimens are received.
\end{abstract}

\section{Introduction}

Laboratory confirmation of a clinical diagnosis of typhoid fever depends essentially on bacterial culture. Serological diagnosis by bacterial agglutination test (the Widal test) is of limited value, being useful in some cases but confusing in others. Problems associated with the Widal test have been discussed elsewhere. ${ }^{12}$ The test result is particularly difficult to interpret in areas where typhoid and other salmonellosis are endemic. Moreover, some patients with typhoid do not develop anti-O, anti-H, or anti-Vi antibodies to diagnostic levels throughout their illness.

Recently Gupta and $\mathrm{RaO}^{3}$ described a counterimmunoelectrophoresis test using an ultrasonic lysate prepared from Salmonella typhi to detect specific antibodies in patients with typhoid and reported promising results. We, however, found that the ultrasonic lysate reacted with a high proportion of sera obtained from normal subjects; a protein antigen extracted from $S$ typhi gives better results with fewer false-positive values. ${ }^{4}$ This prompted us to look for a more specific antigen that would give better differentiation between patients with typhoid and noninfected people. We therefore compared three antigenic extracts (veronal buffer extract, Barber's protein extract, and ultrasonic lysate), all prepared from acetone-treated cells of $S$ typhi, and present the results in this paper. As typhoid fever and other salmonellosis are endemic in Hong Kong our results might be of particular interest in assessing the diagnostic value of counterimmunoelectrophoresis in areas in which these diseases are endemic.

\footnotetext{
Department of Microbiology, University of Hong Kong, Queen Mary Hospital Compound, Hong Kong

RAYMOND S W TSANG, MMEDSC, research student PAK Y CHAU, MRCPATH, senior lecturer
}

\section{Subjects and Methods}

Subjects and serum specimens-We collected 52 sera (including repeated specimens) from 41 patients with typhoid confirmed bo positive blood culture and 62 sera from 34 non-infected norma subjects and 28 patients with a febrile illness that was not typhoid none of these controls had a history of typhoid vaccination. WQ excluded typhoid fever in the 28 febrile patients by obtaining not onlos negative clinical and laboratory findings but also positive findings such as the confirmation of infective endocarditis by blood culture or of urinary tract infection by repeated urine cultures. All the sera except one from the patients with typhoid were collected after the first ween of infection. We deliberately included in the study six sera from five patients with typhoid whose sera repeatedly gave Widal titres below. the diagnostic level.

Widal agglutination test-Antibodies against $S$ typhi $\mathrm{O}$ and $\mathrm{H}$ anti gens were titrated by the tube method using standard stained antigen suspensions (Wellcome Laboratories, England)

Preparation of antigens used for counterimmunoelectrophoresis -5 Antigens were prepared from acetone-dried cells of a $S$ typhi $\mathrm{O}$ straiff NCTC 5753. Flasks with brain heart infusion agar were seeded with 97 log-phase broth culture of this strain and incubated at $37^{\circ} \mathrm{C}$ overnight $S$ typhi cells were washed off from the agar surface with sterileo physiological saline and inactivated overnight with three volumes of acetone at $37^{\circ} \mathrm{C}$. Cells were then washed three times with acetone and dried over a clean filter paper. Veronal buffer extract was prepared by suspending $1 \mathrm{~g}$ of these acetone-fixed cells in $20 \mathrm{ml}$ of $0.1 \mathrm{~mol}$ verona buffer $/ 1$ at pH 8.4 and shaking gently at $37^{\circ} \mathrm{C}$ for 24 hours. Cells were removed by centrifugation at $3000 \mathrm{~g}$ for 30 minutes and the superE natant used as antigen. Protein antigens (Barber antigen) were prepared from veronal buffer extract by repeated precipitation wit $10 \%$ trichloroacetic acid according to the method described b\% Barber. ${ }^{5}$ Ultrasonic lysate was prepared by suspending $0.3 \mathrm{~g}$ of acetone-treated cells in $10 \mathrm{ml}$ of distilled water followed by sonicatio for 15 minutes. The lysate was spun at $4500 \mathrm{~g}$ for 30 minutes and th $\vec{g}$ supernatant used as antigen.

Method for counterimmunoelectrophoresis-Microscopic slides $(25 \mathrm{~mm} \times 76 \mathrm{~mm}$ ) were coated with $3.2 \mathrm{ml}$ of $1 \%$ agrose (Sigmes USA) in veronal buffer ( $\mathrm{pH} 8.2$, ionic strength 0.05 ). For each slide six pairs of wells, $3 \mathrm{~mm}$ in diameter and $5 \mathrm{~mm}$ apart (edge to edge were cut in the agrose gel. Wells were filled up to the top $(10 \mu \mathrm{l})$ wit antigen solution on the cathodal side and sera to be tested on the anodal side. The optimal concentrations of antigens were determine by titration against a set of positive sera from patients with typhoid and were adjusted to a protein concentration, as measured by the method of Lowry et $a l,{ }^{6}$ of $2 \mathrm{mg} / \mathrm{ml}$ for Barber antigen and $4 \mathrm{mg} / \mathrm{m}$ for both the ultrasonic lysate and the veronal buffer extract antigens Electrophoresis was done in a Pharmacia flat bed apparatus FBE-3000 containing $300 \mathrm{ml}$ of veronal buffer ( $\mathrm{pH} 8.2$, ionic strength 0.05 ) in each reservoir and using a current of $0.25 \mathrm{~mA} / \mathrm{cm}$ for two and a has hours. Slides were examined for precipitation lines immediately after electrophoresis and again after staining with $0.5 \%$ Coomassie Blues

Biochemical and immunological characterisation of antigens-Proteiß was determined by the method of Lowry et al ${ }^{6}$ using crystallise $\Phi$ bovine serum albumin (Sigma, USA) as the standard. DNA was estimated by the orcinol reaction ${ }^{7}$ and RNA by the diphenylamine method $^{8}$ using deoxyribose and ribose (Sigma, USA) respectively as standards. Reducing sugars were measured by the anthrone reaction ${ }^{*}$ with $\mathrm{D}(+)$-glucose (Merck, West Germany) as standards. Groups of three adult white rabbits were immunised with acetone-dried $S$ typh cells or dialysed veronal buffer extract prepared from $S$ typhi. Antiser 2 collected from these immunised rabbits as well as sera collected from patients with typhoid were used for the immunological characterisatio of the veronal buffer extract antigen by Ouchterlony's double immuno diffusion and by immunoelectrophoresis. A veronal buffer extra\& prepared from a strain of Escherichia coli isolated from the blood of patient with septicaemia was also included in this study for comparison with the extract prepared from $S$ typhi. 


\section{Results}

Table I shows the rates of detection of specific antibodies using counterimmunoelectrophoresis with three different antigenic extracts prepared from $S$ typhi. Fifty $(96 \%)$ of the 52 sera (with repeats) collected from the patients with typhoid reacted with veronal buffer extract to give one to three precipitation lines when examined immediately after electrophoresis, including the six sera for which the Widal test showed titres below the diagnostic level. One of the two patient sera that did not give precipitation lines (even after staining with Coomassie Blue) had been collected in the early acute phase (four days after fever had developed) and had a Widal titre of less than $1 / 40$ for both the $\mathrm{O}$ and $\mathrm{H}$ antibodies. The other patient serum, which had both $\mathrm{O}$ and $\mathrm{H}$ Widal titres greater than $1 / 80$, did not yield visible precipitation lines immediately after electrophoresis but did so after staining with Coomassie Blue. None of the 62 control sera gave visible precipitation lines immediately after electrophoresis, but on staining six sera showed a single faint precipitation line.

TABLE I-Comparison of different antigenic preparations of $S$ typhi for detection of antibodies by counterimmunoelectrophoresis in patients with typhoid and controls

\begin{tabular}{|c|c|c|c|c|}
\hline \multirow{2}{*}{ Subjects } & \multirow{2}{*}{$\begin{array}{l}\text { No of } \\
\text { sera } \\
\text { examined }\end{array}$} & \multicolumn{3}{|c|}{$\begin{array}{l}\text { No (\%) of sera giving precipitation } \\
\text { lines in counterimmunoelectrophoresis } \\
\text { against: }\end{array}$} \\
\hline & & $\begin{array}{l}\text { Veronal } \\
\text { buffer } \\
\text { extract }\end{array}$ & $\begin{array}{l}\text { Ultrasonic } \\
\text { lysate }\end{array}$ & $\begin{array}{c}\text { Barber } \\
\text { antigen }\end{array}$ \\
\hline \multicolumn{5}{|c|}{ Results read immediately after electrophoresis } \\
\hline $\begin{array}{l}\text { Patients with typhoid } \\
\text { Controls }\end{array}$ & $\begin{array}{l}52 \\
62\end{array}$ & $\begin{array}{c}50 \\
0\end{array}$ & $\begin{array}{l}39(75) \\
13(21)\end{array}$ & $\begin{array}{c}36(69) \\
1(2)\end{array}$ \\
\hline \multicolumn{5}{|c|}{ Results read after staining with Coomassie Blue } \\
\hline $\begin{array}{l}\text { Patients with typhoid } \\
\text { Controls }\end{array}$ & $\begin{array}{l}52 \\
62\end{array}$ & $\begin{array}{r}51(98) \\
6(10)\end{array}$ & $\begin{array}{l}50(96) \\
20(32)\end{array}$ & $\begin{array}{l}51(98) \\
3(5)\end{array}$ \\
\hline
\end{tabular}

Barber antigen and ultrasonic lysate, respectively, yielded precipitation lines against $36(69 \%)$ and $39(75 \%)$ of the 52 sera from patients when examined immediately after electrophoresis, although rates $(98 \%$ and $96 \%$, respectively) similar to those for veronal buffer extract were obtained after staining with Coomassie Blue. Barber antigen formed precipitation lines against one $(2 \%)$ and ultrasonic lysate antigen against $13(21 \%)$ of the 62 control sera when examined immediately after electrophoresis, and against three $(5 \%)$ and 20 $(32 \%)$, respectively, after staining with Coomassie Blue.

Table II summarises the $\mathrm{O}$ and $\mathrm{H}$ antibody titres in the sera of the patients and controls. Altogether $75 \%(39 / 52)$ and $87 \%(45 / 52)$, respectively, of the serum samples from the patients with typhoid had $\mathrm{O}$ and $\mathrm{H}$ antibody titres reaching diagnostic level, which was arbitrarily defined as $1 / 80$. Using this criterion an appreciable proportion of the control sera $(23 \%(14 / 62)$ using anti-O and $32 \%$ $(20 / 62)$ using anti-H antibody titre alone) would be defined as positive for the disease by the Widal agglutination test. If having both $O$ and $\mathrm{H}$ antibody titres $\geqslant 1 / 80$ was considered to be diagnostic then the positive rate for patients' sera was $73 \%(38 / 52)$ and the false-positive rate for control sera $16 \%(10 / 62)$.

Of the nine patients with typhoid in whom paired serum specimens were obtained one week apart, only one showed a fourfold rise in both $\mathrm{O}$ and $\mathrm{H}$ antibody titres. In the remaining eight patients no fourfold rise in either titre was noticed, indicating that diagnosing typhoid fever by the finding of a fourfold rise on $\mathrm{O}$ or $\mathrm{H}$ antibody titres ${ }^{10}$ is impractical.
Table III shows data on the biochemical analysis of the antigen preparations. Ultrasonic lysate contained a large proportion of nucleic acid while veronal buffer extract, prepared by a much milder extraction procedure, contained much less. Precipitation with trichloroacetic acid to prepare Barber antigen from veronal buffer $\mathbb{\Phi}$ extract lowered substantially the proportion of reducing sugars. $C$ Veronal buffer extract prepared from $S$ typhi was found by immunoelectrophoresis to contain at least three cathodal and six anodal migrating antigenic components (fig 1), some specific for $S$ typhi and 70 at least one in common with $E$ coli when compared with veronal buffer ${ }_{\infty}^{\mathbb{D}}$ extract prepared from $E$ coli (fig 2).

TABLE III-Biochemical analysis ( $\mu \mathrm{g} / \mathrm{mg}$ protein) of ultrasonic lysate, veronat $\overrightarrow{\overline{\mathrm{c}}}$ buffer extract, and Barber's protein antigens prepared from acetone-treated cells of $S$ typhi

\begin{tabular}{lccc}
\hline Preparation & DNA & RNA & $\begin{array}{c}\text { Reducing } \\
\text { sugars }\end{array}$ \\
\hline Ultrasonic lysate & 161 & 794 & 54 \\
Veronal buffer extract & 19 & 123 & 44 \\
Barber's antigen & 58 & 54 & 6 \\
\hline
\end{tabular}

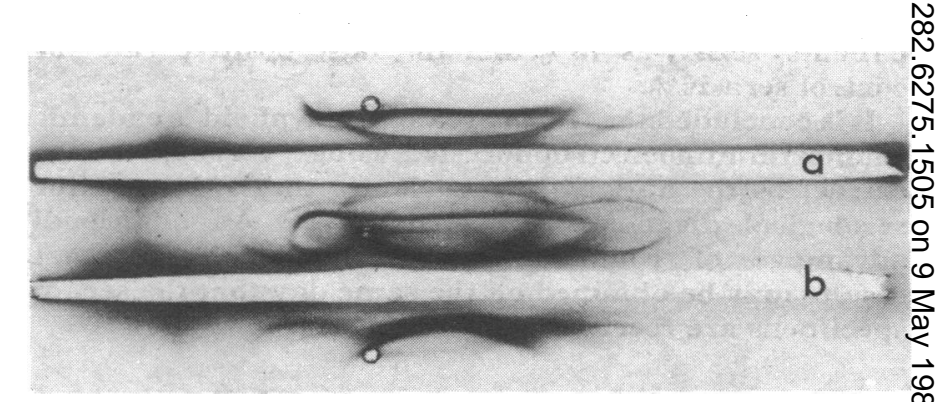

FIG 1-Immunoelectrophoretic analysis of veronal buffer extract prepared from $S$ typhi against sera from rabbits immunised $(a)$ with acetone-fixed whole cells of $S$ typhi and (b) with veronal buffer extract prepared fromo $S$ typhi.

\section{Discussion}

A bacterial agglutination test is conventionally used for the serological diagnosis of enteric fever and some other Gram-? negative bacterial infections such as brucellosis. Precipitation reactions using extracts from bacteria have not been fully explored in this respect. Although Gupta and $\mathrm{RaO}^{3}$ reported success with counterimmunoelectrophoresis using a centrifuged $<$ ultrasonic lysate prepared from $S$ typhi to detect antibodies in typhoid patients, we found that this antigen gave too high $\mathrm{a}_{\mathrm{h}}$ false-positive rate to be of any practical value. This might be dueO to the release by ultrasonication of some cross-reacting antigenic components such as glycolipids, which are buried deep in the bacterial membrane ${ }^{11}$ and are heavily cross-reacting among manyN Gram-negative bacteria. ${ }^{12} 13$

Veronal buffer has been used to extract antigens from bacteria, ${ }^{14}$ and the resulting crude extract contains many antigenic components including the $\mathrm{O}$-specific side chains of then

TABLE II-Anti $S$ typhi $O$ and $H$ antibody titres in sera of 41 patients with typhoid and 62 controls

\begin{tabular}{|c|c|c|c|c|c|c|c|c|c|c|c|}
\hline \multirow{2}{*}{$\begin{array}{l}\text { Total No } \\
\text { of sera } \\
\text { examined }\end{array}$} & \multirow{2}{*}{$\begin{array}{l}\text { Type of } \\
\text { antibody }\end{array}$} & \multicolumn{6}{|c|}{ No of sera with reciprocal titre of: } & \multicolumn{3}{|c|}{$\begin{array}{l}\text { No of sera with } \\
\text { reciprocal titre of: }\end{array}$} & \multirow{2}{*}{$\begin{array}{r}\text { No }(\%) \text { of sera with } \\
\text { both O and } \mathrm{H} \text { antibod } \\
\text { reciprocal titres } \geqslant 80\end{array}$} \\
\hline & & $\geqslant 1280$ & 640 & 320 & 160 & 80 & Total (\%) & 40 & $\leqslant 20$ & Total (\%) & \\
\hline \multicolumn{12}{|c|}{ Patients with typhoid } \\
\hline 52 & $\stackrel{\mathrm{O}}{\mathbf{H}}$ & $\begin{array}{r}4 \\
16\end{array}$ & $\begin{array}{r}8 \\
11\end{array}$ & $\begin{array}{r}13 \\
6\end{array}$ & $\begin{array}{r}10 \\
8\end{array}$ & $\begin{array}{l}4 \\
4\end{array}$ & $\begin{array}{l}39(75) \\
45(87)\end{array}$ & $\begin{array}{l}5 \\
0\end{array}$ & $\begin{array}{l}8 \\
7\end{array}$ & $\begin{array}{r}13(25) \\
7(13)\end{array}$ & $38(73)$ \\
\hline \multicolumn{12}{|c|}{ Controls } \\
\hline 62 & $\stackrel{\mathrm{O}}{\mathrm{H}}$ & $\begin{array}{l}\mathbf{0} \\
\mathbf{0}\end{array}$ & $\begin{array}{l}0 \\
1\end{array}$ & $\begin{array}{l}0 \\
4\end{array}$ & $\begin{array}{l}3 \\
6\end{array}$ & $\begin{array}{r}11 \\
9\end{array}$ & $\begin{array}{l}14(23) \\
20(32)\end{array}$ & $\begin{array}{r}10 \\
9\end{array}$ & $\begin{array}{r}38 \\
33\end{array}$ & $\begin{array}{l}48(77) \\
42(68)\end{array}$ & $10(16)$ \\
\hline
\end{tabular}


lipopolysaccharide antigens and the surface protein antigens, which are probably released as native molecules by this mild extraction procedure. Using veronal buffer extract as the antigen in counterimmunoelectrophoresis, we achieved a $96 \%$ detection rate with no false-positive results immediately after electrophoresis without staining.

Protein antigens are protective in experimental animal salmonellosis, ${ }^{15}{ }^{17}$ but their importance has not been studied in human typhoid infections and there have not been any reports that anti-protein antibodies are produced in patients with typhoid. Using counterimmunoelectrophoresis, we found that $98 \%$ of sera from patients with typhoid reacted with Barber

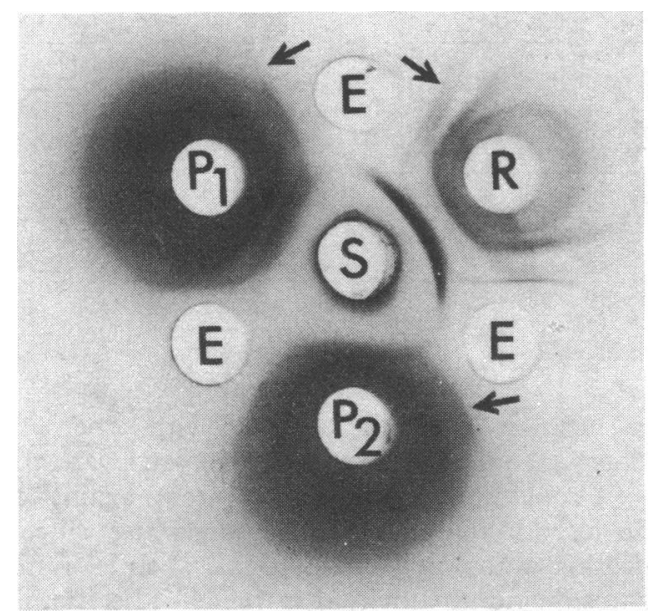

FIG 2-Demonstration of common antigen (indicated by arrow) between $S$ typhi and $E$ coli.

$\mathrm{S}=$ Veronal buffer extract prepared from $S$ typhi. $\mathrm{E}=$ Veronal buffer extract prepared from $E$ coli. $\mathrm{R}=$ Serum from rabbit immunised with acetonetreated whole cells of $S$ typhi. $\mathrm{P}_{1}$ and $\mathrm{P}_{2}=$ sera obtained from two patients with typhoid.

antigen to give precipitation lines. Most of these lines, however, were weak and faint (in $29 \%$ of patients' sera precipitation lines were evident only after staining with Coomassie Blue) when compared with precipitation lines formed against veronal buffer extract.

With the Widal test an appreciable proportion (16\%) of the normal control sera had both $O$ and $H$ antibody titres $\geqslant 1 / 80$, which we chose arbitrarily as the diagnostic titre. These results agree with those of Levine et al, ${ }_{1}^{1}$ who concluded that a single Widal test has no diagnostic value in an area where typhoid is endemic. Even when paired serum specimens obtained one week apart were used, only one out of nine pairs showed a fourfold rise in titres. Thus counterimmunoelectrophoresis using veronal buffer extract as the antigen is superior to the Widal test in an area like Hong Kong where the disease is endemic. An additional advantage is that the results may be read immediately after electrophoresis-that is, on the same day that the serum specimens are received. In a radioimmunoassay study of the antibodies to the lipopolysaccharide and protein antigens of $S$ typhi contained in patients' sera we found that a considerable proportion were of the IgG class (unpublished data). This might explain why almost all the sera from patients with typhoid gave precipitation lines against veronal buffer extract, ultrasonic lysate, and Barber's protein antigens, though with the latter two antigens staining with Coomassie Blue was sometimes required to make the lines clearly visible.

The finding of an antigenic component common to $S$ typhi and $E$ coli in their respective veronal buffer extract preparations was interesting. The $10 \%$ false-positive rate with veronal buffer extract antigen in the control sera (observed after staining with Coomassie Blue; see table 1) might be related to the presence of this common antigen. Hence removal of this common antigen by fractionation of the veronal buffer extract prepared from $S$ typhi should help to increase the specificity of this counterimmunoelectrophoresis test.

This study was supported by a WHO research grant from the Diarrhoeal Disease Control Programme to PYC and by the Wu Chung Medical Research Fund of the University of Hong Kong.

\section{References}

${ }^{1}$ Levine MM, Grados O, Gilman RH, Woodware WE, Solis-Plaza $\mathbf{R}$, Waldman W. Diagnostic value of the Widal test in areas endemic for typhoid fever. Am 7 Trop Med Hyg 1978;27:795-800.

2 Anonymous. Typhoid and its serology. $\mathrm{Br}$ Med $\mathcal{F}$ 1978;i:389-90.

3 Gupta AK, Rao KM. Simultaneous detection of Salmonella typhi antigen and antibody in serum by counterimmunoelectrophoresis for an early and rapid diagnosis of typhoid fever. Immunological Methods $1979 ; 30$ 349-53.

${ }^{4}$ Chau PY, Tsang RSW, Ng A. New method for serological screening of typhoid carriers. Lancet 1980 ;ii:695-6.

5 Barber C. Le tampon-veronal, moyen d'extraction des antigens bactériens. Arch Roum Pathol Exp Microbiol 1961;20:541-3.

6 Lowry OH, Resebrough NJ, Fan AL, Randall RJ. Protein measurement with the Folin phenol reagent. 7 Biol Chem $1951 ; 193: 265-75$

7 Gioranni C. Determination of nucleic acids in animal tissue. $\mathcal{f} \mathrm{Mol} \mathrm{Bio}$ 1955;193:59-70.

${ }^{8}$ Burton K. A study of the conditions and mechanism of the diphenylamine reaction for the colorimetric estimation of deoxyribonucleic acid. Biochem F 1956;62:315-23.

${ }^{9}$ Roe JH. The determination of sugar in blood and spinal fluid with anthrone reagent. $f$ Biol Chem 1955;212:335-43.

10 Farmer SG, Tilton RC. Immunoserological and immunochemical detection of bacterial antigens and antibodies. In: Lennette $\mathrm{EH}$, Balows A, Hausler WJ, Truant JP, eds. Manual of clinical microbiology. 3rd ed. Washington, DC: American Society for Microbiology, 1980:524.

${ }^{11}$ Mullan NA, Newsome PM, Cunnington PG, Palmer GH, Wilson ME Protection against gram-negative infections with antiserum to lipid $\mathbf{A}$ from Salmonella minnesota R595. Infect Immun 1974;10:1195-201.

$12 \mathrm{Ng} \mathrm{AK}$, Chen CH, Chang CM, Nowotny A. Relationship of structure to function in bacterial endotoxins : serologically cross-reactive components and their effect on protection of mice against some gram-negative infections. 7 Gen Microbiol 1976;94:107-16.

13 Johns MA, Bruins SC, McCabe WR. Immunization with $\mathrm{R}$ mutants of Salmonella minnesota. II. Serological response to lipid $\mathrm{A}$ and the lipopolysaccharide of Re mutants. Infect Immun 1977;17:9-15.

14 Holmgren J, Eggertsen G, Hanson LA, Lincoln K. Immunodiffusion studies on Escherichia coli. I. Identification of $\mathrm{O}, \mathrm{K}$ and $\mathrm{H}$ antigens in an O6 strain. Acta Pathol Microbiol Scand 1969;76:304-18.

15 Barber C, Eylan E. Confirmation of the protective role of proteins from Salmonella typhimurium in infection of mice with their natural pathogen. Zentralbl Bakteriol [A] $1975 ; 230: 461-5$.

16 Plant J, Glynn AA, Wilson BM. Protective effect of a supernatant factor from Salmonella typhimurium on Salmonella typhimurium infection of inbred mice. Infect Immun 1978;22:125-31.

17 Kuusi N, Nurminen M, Saxen H, Valtonen M, Makela PH. Immunization with major outer membrane proteins in experimental salmonellosis of mice. Infect Immun $1979 ; 25: 857-62$.

(Accepted 9 March 1981)

ONE HUNDRED YEARS AGO At this season of the year, tons of trash under the name of pork-sausages are thrown upon the market, and find a very ready sale; but, instead of being made wholly of pork, they are interspersed with the remnants of "block-ornaments"-no matter whether of beef, mutton, or veal-these latter being consigned to the sausage-mill when their appearance is no longer tempting enough to secure a purchaser. Any taint or unpleasant flavour is roughly disguised by the amount of seasoning used. In the raw state, they are not easily detected; but, on being cooked, they are readily distinguishable by their red and under-done appearance, as compared with that of the genuine porksausage, which presents, when cooked, an uniformly white colour throughout. Mouldy bread, tainted livers, and other equally dubious material, are common ingredients of cheap sausages. This, doubtless, accounts for some of the fatality from diarrhoea during the winter months. It is time that sausage and "polony" manufactories were under more rigid and systematic inspection; and that attaching to this food of the poor there should be a better guarantee of its wholesomeness. (British Medical fournal, 1881.) 